\title{
Prospects for Food and Agriculture in 1975
}

\author{
CLIFTON B. LUTTRELL and NEIL A. STEVENS
}

约

ONSUMERS can expect average retail food prices to increase at an annual rate of about 10 percent in the first half of 1975 , according to the United States Department of Agriculture (USDA). The projected increase is based on prospects for a slight decline in per capita supplies and a high but slowing rate of demand growth. Cutbacks in production of most animal products will lead to price increases for many of these foods, and prices of most crop foods will also increase.

Food price estimates for the second half of 1975 are less certain. Larger food crops this year and an anticipated slower rate of increase in marketing costs could lead to a reduction in the upward pressure on retall food prices after mid-year.

Realized net farm income will likely be less than the $\$ 27.2$ billion estimated for 1974. Receipts from farm product sales are expected to increase, but somewhat less than the rise in production expenses.

This article discusses the prospects for food and agriculture this year. The material presented is based primarily on reports given at the $1975 \mathrm{National} \mathrm{Agri-}$ cultural Outlook Conference and other recent USDA releases.

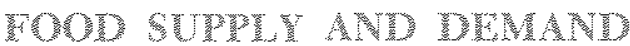

Farm product and food prices have risen sharply during the past three years. Average farm product prices rose at an annual rate of 18 percent from 1971 to 1974 while retail food prices rose at an 11 percent rate. These rapid price increases can be attributed largely to rising food demand, since production was above the long-run trend (see accompanying chart).

Supply and demand forces a year ago indicated a slowdown in the rate of increase of food prices. Famers, responding to the higher prices, implemented plans to increase production of most crops and livestock. However, adverse weather conditions led to an 8 percent decline in overall crop production and higher crop prices. Thus, despite some decline in livestock prices, average farm product prices were higher than a year earlier.

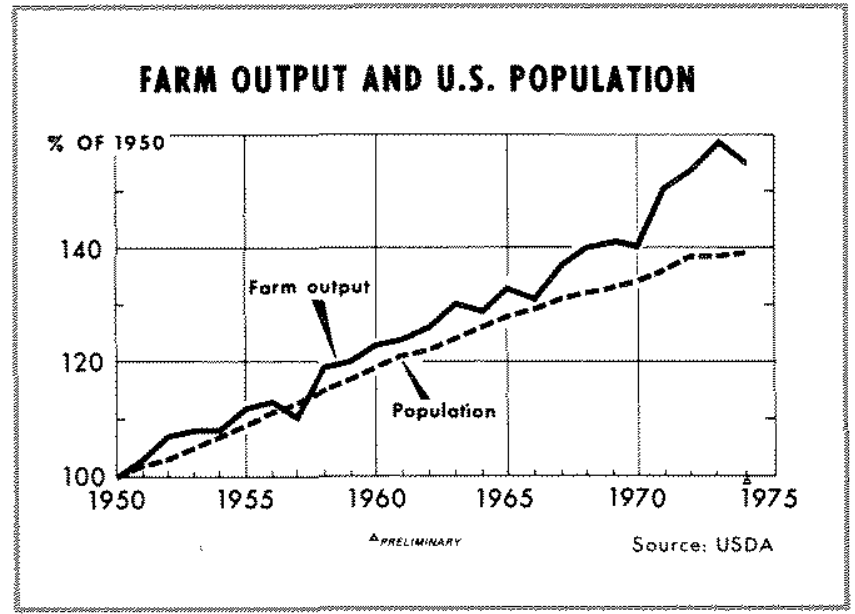

Again this year supply and demand factors point to a slower growth in food prices than last year's 15 percent rate. Bumper crops could lead to a significant slowing in price increases in the second half of the year. Also a reduction in the growth rate of the farmto-retail price spread should have a favorable impact on food prices. Much of the food price increase in 1974 reflected higher marketing margins rather than major increases in prices at the farm. The increase in the farm-retail margin accounted for over 80 percent of the increase in the average retail price. These wider margins are attributed to an acceleration in marketing costs and a recovery from the depressed margins during the period of price controls and sharply rising farm product prices in 1972 and 1973.

Marketing margins are expected to rise further in the first half of 1975 , but the increase is likely to be at a more moderate rate than last year as the influence of the recent period of price controls and the higher petroleum prices subsides. On the other hand, the threat of a reimposition of wage and price controls may contribute to somewhat higher marketing margins than would otherwise prevail.

As a result of a slower rate of monetary growth since mid-1974, some moderation in the growth of consumer spending may occur this year. Nevertheless, with a slight reduction in the per capita food supply and rising prices, an increase in the percentage of consumer income spent on food is likely. The 
increase, however, will not be very large since consumers will shift from higher-priced to lower-priced foods. In the past two years consumer expenditures for food have outpaced increases in consumer income, thus reversing the long-run downtrend in the percentage of such income spent on food. Consumers spent 16.8 percent of their income on food in $1974,15.9$ percent in 1973, and a historical low of 15.4 percent in 1972 (see Table I).

Although export demand for farm products is expected to remain relatively strong in 1975 , export volume will likely be down about 20 percent from last year as a result of reduced crop production last fall and higher prices. The dollar value of such exports, however, may be slightly above the record $\$ 21.3$ billion last year. The high export demand reflects reduced world grain crops in 1974 coupled with the lowest stock levels in more than two decades. Feed grain exports are likely to be down about 25 percent from the 44 million tons last year but will still total about 20 percent of 1974 production, only slightly less than the percentage exported last year. On the other hand, wheat exports are forecast at 1.1 billion bushels, slightly less than a year ago, and rice exports are projected at a record 74.5 million cwt., 50 percent more than a year ago.

Increases in exports to a number of developing countries, including India and parts of Southeast Asia and Africa, are in prospect. These nations are suffering from extreme food shortages; however, they have little means of financing food purchases and most shipments to them will require subsidized financing through Public Law 480 .

As pointed out at the Outlook Conference ${ }^{1}$, part of the food shortage problem in the less developed portion of the world is the result of unwise farm policies such as the artifially high support prices pursued in the more developed nations during the past two decades. The resulting surpluses were used to provide large amounts of food aid to the less developed nations, which inhibited their food production and led to further imbalances in their population-food production ratio. Consequently the reductions in world grain production in 1972 and 1974 and the removal of most govermment price supports in this country left the developed portion of the world without surplus grain and the less developed nations in an extremely vulnerable position.

1Harry Walters, The World Food Stuation (a speech delivered at the 1975 National Agriculfural Outlook Conference, Washington, D.C., December 9, 1974), pp. 4, 5, 8 .

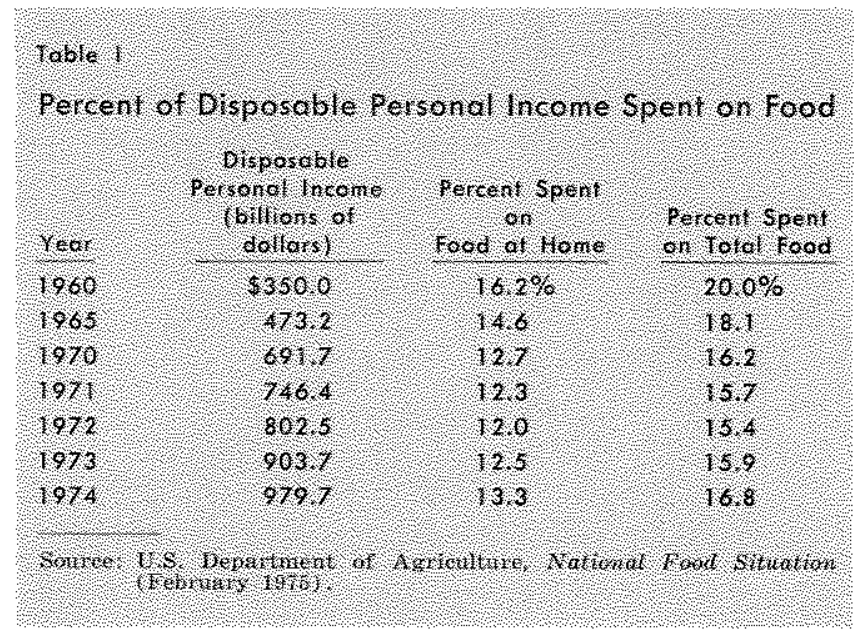

The quantity of food available for consumption in the United States in the first half of this year will likely be somewhat less than a year ago, due to the expected decline in livestock products. Beef supplies will be relatively large, but pork, mutton, poultry, eggs, and dairy products will decline. Somewhat larger crop food supplies are in prospect, aided by a larger supply of potatoes, rice, citrus fruits, dried beans, and peas.

The quantity of food available to consumers in late 1975 will be determined in part by forces that affect farmers' production plans in the early part of the year. These factors are mixed. On the one hand, farmers have probably not fully adjusted to the recent crop price increases and the lifting of Government supply restrictions last year. This will tend to expand crop acreages. On the other hand, such expansion will be limited by rising production costs. Farmers, for example, are faced with sharply higher fertilizer, machinery, and land prices. Fertilizer prices in late 1974 were 82 percent above last March when the 1974 crop was planned. Higher oil prices in the coming months are also likely. The rate of increase of farm machinery prices may slacken this year, but in late 1974 such prices were 23 percent above those of a year earlier. Pesticice supplies may be short in 1975 due to high world demand and a lack of plant expansion in this industry in recent years. Expansion of agricultural output may also be hindered by increased uncertainty about regulations, price controls, and the availability of fertilizer and other inputs.

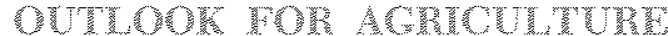

The year 1974 was a turbulent one for feed grain and livestock farming. A substantial reduction in feed grain production and the production lag in live- 
stock output resulted in producers of grains and livestock receiving radically different price signals. What these signals mean in terms of prospective ontput and prices for the feed grain-livestock sectors and the outlook for important food crops are discussed in this section.

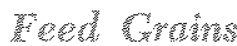

Feed grain production declined 20 percent last year as a result of the worst crop growing conditions in thirty years. This decline was one of the largest in the post World War II period. It compares with other major declines of 24 percent in 1947, and declines of 10 to 13 percent in 1949, 1961, 1964, and 1970. Each of these declines reflected reduced yields per acre except in 1961 when crop production controls were more restrictive and the acreage planted was reduced.

Compounding the problems associated with lower feed grain production last year were the relatively low levels of begimning stocks. During the $1950 \mathrm{~s}$ and 1960s large Government stocks, in addition to private holdings, helped to offset the effects of production shortfalls. For example, despite the production decline of 12 percent in 1949 the total quantity of feed grain available was actually larger than in the previous year. In $1961-62$ the quantity available was down only 2.3 percent, and in 1964-65 and 1970-71 the quantity was down only 6.7 and 8.3 percent, respectively. In contrast, this year the quantity is dow over 21 percent.

The cutback in the 1974-75 feed grain crop resulted in sharp increases in feed grain prices last fall. Feed grain prices have declined since the end of the year, but they are still relatively high and farmers are likely to increase the number of acres of feed grain crops despite higher production costs. Hence, with tavorable weather, larger supplies of crops are in prospect for 1975. For example, corn yields should average 90 bushels or more per harvested acre, compared with 71.3 bushels last year; with a moderate rise in acreage this would result in a record crop. A total feed grain crop of 30 to 50 pereent above last year's 165 million tons is possible, and unless the livestock industry turns sharply upward and exports rise by an unusual amount, this record level of production would result in a build-up of stocks for the 1975-76 marketing year.

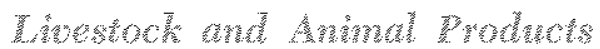

High feed prices and rising prices of other inputs coupled with relatively low livestock product prices

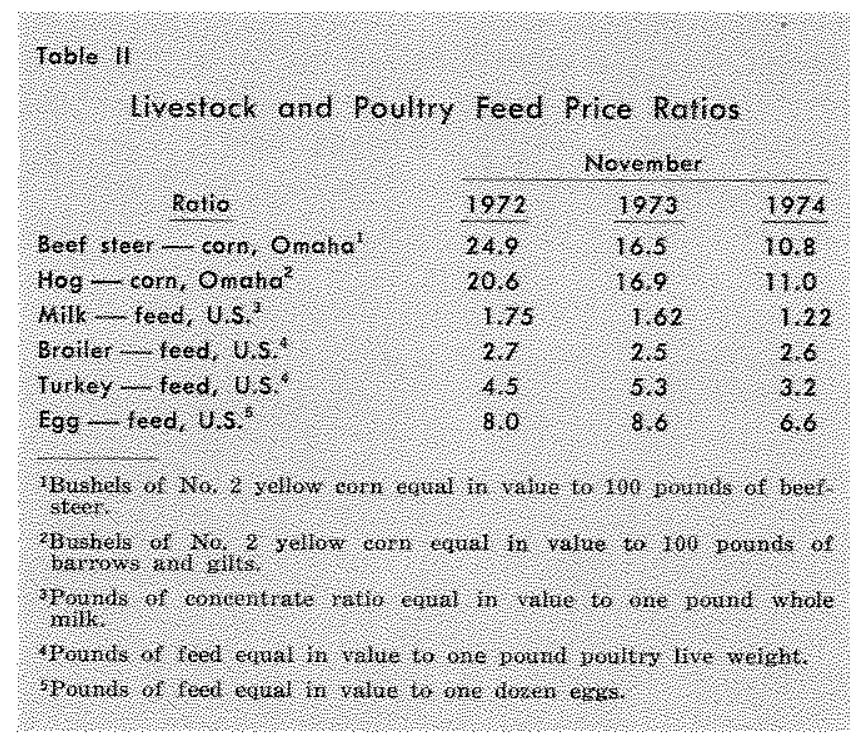

last year resulted in a drastic reduction in the profitability of livestock feeding. With rising costs and little change in the price of meat, poultry, dairy products, and eggs, major losses were realized in most feeding operations. One indicator of this unprofitable situation was the reduced livestock-feed price ratios. Last November the beef-corn price ratio stood at 10.8 (bushels of corn equal in value to 100 pounds of beef-steer), compared with 24.9 and 16.5 in 1972 and 1973 , respectively. Most other livestock and livestock product feed price ratios were also well below levels in late 1972 and 1973 (see Table II). This unprofitable situation for livestock production is leading to considerable adjustments in the livestock industry. The farmer, in plaming production, weighs the expected returns against the associated costs. If the profit outlook is good, he will likely expand his operations. Conversely, if profits look bleak, he will cut back or quit such operations altogether.

Castle -..- Cattle feeders had already made considerable cutbacks last fall, having experienced financial losses since late 1973. The number on feed in the major feeding states was 37 percent less in February than a year earlier, and fed cattle marketings declined. Nevertheless, fed cattle prices have declined. They rose last summer, but declined in the fall as a result of rising non-fed beef supplies.

As demand for feeder cattle waned, cow-calf operators began to experience losses. Feeder catile prices fell from $\$ 49$ per cwt. in early 1974 to $\$ 24$ in early 1975. These price declines led to a sharp increase in slaughter of non-fed cattle which more than offset the decline in fed cattle slaughter. The increased slaughter came from culled cows, calves, and a dramatic in 
crease in non-fed and short-fed steers and heifers. Nevertheless, with the largest inventory of cattle in history, the number of beef cattle on farms and ranches continued to build up. By early 1975 total cattle numbers were up 4.2 million, or 3 percent from a year earlier.

The number of cattle slaughtered this year may be up 10 to 15 percent from a year ago, but the timing will be dictated largely by pasture and range conditions and feed prices. Marketings may decline during the spring months as pastures improve, but beef supplies for the year are expected to be larger than last year despite some reduction in the average weights of steers and heifers and increased calf slaughter. However, the larger supplies of beef may not result in much decline in beef prices as higher prices for other meats will tend to place upward pressure on cattle prices. Choice cattle prices may thus be somewhat higher this spring than the $\$ 37$ per cwt. late last year.

The lower weights of marketed cattle is the industry's response to low feeding margins. By marketing cattle at reduced weights, more pounds of beef can be produced with a given amount of grain, and total beef production from the current cattle inventory will be reduced. Nevertheless with the large cattle inventory, next year's calf crop is still expected to be larger than this year's, but the rate of increase will be lower. Thus barring severe weather conditions for pastures and feed production, cattle numbers will continue to increase through 1975 providing a base for a greater beef production in the coming years.

Hogs - The hog inventory has declined since 1971; thus the adjustment problem for hog producers is not as severe as for cattle producers. Hog producers reacted strongly to a reduction in profits last year and began to reduce breeding inventories. Sow slaughter last fall rose 50 percent from a year earlier, and 10 percent fewer sows were farrowed during the September-November period than a year earlier. Another reduction is expected during the December 1974 May 1975 period.

The cutback in farrowing will lead to a reduction in pork production. Pork production in the first quarter of this year is likely to be down 8 percent from a year earlier and 10 percent from the fourth quarter of last year; further reductions are likely in the second quarter. Since feed prices are likely to remain high and the expected reduction in the December-May pig crop is likely to be realized, higher hog prices are in prospect throughout 1975 .

Fall farrowing in 1975 may remain relatively low even with large grain crops and lower grain prices, since hog producers have traditionally not expanded farrowings in the fall months. With significantly lower corn prices an expansion in farrowing might take place early next year, resulting in a pick-up in hog slaughter in the second half of the year.

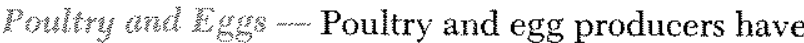
made cutbacks in egg, broiler, and turkey production as a result of reduced profits. Ratios of poultry and egg prices to feed prices during most of last year were consistently unfavorable to producers relative to other recent years.

Egg production declined in the second half of last year relative to a year earlier, and with the reduced laying flock, production in the first half of 1975 may average 5 percent below a year ago. Replacement chicks for early 1975 are down from a year ago and eggs in incubators to provide pullets for early summer are also down. Thus lower egg production is likely through most of 1975. Egg prices, however, were somewhat lower than a year ago through the first quarter of the year, and may show some further decline in the spring.

Broiler production in 1974 averaged about the same as a year earlier, although production was declining in the last quarter. Broller prices have been relatively high for several months, but with high feed costs, there is little incentive to expand output. Broiler chicks and egg sets for January-March marketings were down 8 percent from a year ago; production during the first half of the year is likely to be down by about the same percentage. As production declines, prices are expected to move up through the first half of 1975 , and the profit level in the first half will determine production in the second half of the year.

Turkey production in 1974 was slightly above a year earlier, although production dropped below yearearlier levels in the latter part of the year. Turkey output in the first half of 1975 will likely be down substantially from a year ago and prices higher as poult placements for marketing in early 1975 dropped 13 percent.

Dexty -... Milk production was estimated at 115.4 billion pounds in 1974, about the same as in 1973 . Milk output is expected to remain about the same in early 1975 as a year ago, and output for the second 
half of 1975 will largely depend on prospects for feed grain production.

\section{rood Crops}

Food Craiss - Strong world demand for wheat coupled with a relatively small increase in U.S. production has resulted in a sharp reduction in wheat stocks and higher average prices. U.S. production last year was up only 5 percent from a year earlier despite a 19 percent increase in acreage. Consequently, the total U.S. wheat supply for $1974-75$ is 5 percent below that of last year.

High wheat prices last fall led to a 6 percent increase in the acreage seeded to winter wheat, and a moderate increase is in prospect for spring wheat acreage. Spring wheat planting will be limited, however, by strong competition for cropland from other crops.

In contrast to the relatively small increase in wheat output, rice production increased 23 percent from 1973 to 1974 . Rice prices in January were only twothirds as high as a year earlier, but lower world production last year is likely to keep demand for zice exports strong and prices firm.

Reflecting reduced production last year, soybean supplies in the current marketing year are down 13 percent and soybean oil and meal supplies, the main derivatives of soybeans, are down 6 and 7 percent, respectively, from a year ago. Nevertheless, soybean prices in early March were well below those of a year earlier.

Soybean acreage this year may be up from a year ago. The soybean-corn price ratio is about 2 to 1 which will tend to encourage farmers to substitute corn for soybeans. On the other hand, the price relationship between soybeans and cotton tends to favor the substitution of soybeans for cotton. Hence, with normal weather and the expected higher yields per acre, soybean production in 1975 could be welf above last year's level.

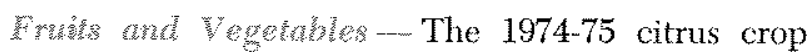
was about 6 percent larger than a year earlier and slightly larger than the $1972-73$ record output. Noncitrus fruit production last year was about the same as in 1973 , but the supply of processed non-citrus fruits is above a year ago.

Supplies of processed vegetables are moderately larger than a year ago as a result of increased supplies of tomatoes and some frozen vegetables. Fresh vege- table supplies were down last fall and this winter, and prices were somewhat higher than a year earlier. Production will primarily determine price movements later in the year. A record fall potato crop has resulted in lower potato prices, and a large dry bean and pea crop induced by high 1973 prices has resulted in price declines for these items.

Sugar - Sugar prices rose five-fold last year leading to sizable price increases for all sugar-using products. Both U.S. and world sugar prices exceeded 55 cents a pound in late 1974, up from 11 cents a year earlier. The United States imports about 50 percent of the sugar it consumes; thus supply and demand conditions in other nations are major factors in determining domestic sugar prices.

Part of the sharp price increase can be traced to ill-advised price and production regulations in the major producing countries. World sugar consumption has exceeded production for the past three years. Stocks have been reduced to relatively low levels, but output and consumption did not respond to declining stocks and rising domestic prices as would have been expected. Growers in some nations were compelled to sell their sugar at artificially low prices and, consequently, had little incentive to increase production. Also, consumers in some nations were permitted to purchase sugar at artificially low prices and had little incentive to reduce consumption. In addition, rising demand for sugar from the petroleum exporting countries contributed to the upward price movement.

Sugar prices have tended to moderate since last fall. However, they are still very high compared with recent years and are expected to stimulate sugar production this year in those nations that permit price increases to be passed on to producers. For example, U.S. sugarbeet growers on January 1 indicated that they would increase their acreage planted to sugarbeets this year by 20 percent.

\section{Nowhore Brops}

Cotton production in 1974 fell 10 percent from the previous year as a result of adverse weather conde. tions. Despite the lower production, cotton prices have declined substantially from their peaks last winter, reflecting a decline in demand. Demand for all fibers declined as demand for textiles fell off, causing a large buildup in textile inventories.

Prospects for cotton production in 1975 hinge on the producers' reaction to lower cotton prices relative 
to other crops, primarily soybeans, and the higher cotton loan rate. The preliminary loan rate of 34.27 cents per pound for middling 1 -inch cotton is up 9.01 cents from last year. Farmers may plant about 9.5 million acres this year, down from 14.25 million in 1974. On this basis upland production with average yields would total 8.5 to 9.5 million bales, down from 11.7 million in 1974 .

Tobacco production was up 12 percent in 1974 , but lower beginning stocks and strong demand led to rising prices. The 1975 marketing quota for Hue-cured tobacco of 1,492 million pounds is up 15 percent from 1974 , and the burley marketing quota is up 10 percent. The higher quotas combined with relatively high prices will likely mean increased production in 1975 .

\section{Tarm Treome}

Net farm income is expected to be less than a year ago. Cash receipts will probably increase again, reflecting somewhat higher average prices and perhaps larger crops. Production expenses will continue to rise, but the rate of increase should be less than the high rates of the past two years.

Realized net income last year totaled $\$ 27.2$ billion, down from the record high $\$ 32.2$ billion a year earlier. Cash receipts, estimated at $\$ 95$ billion, were up about $\$ 6$ billion from 1973. Realized gross income was up 5 percent, but farm production expenses were up 16 percent.

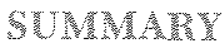

Further increases in food prices are projected for 1975 , especially in the first half of the year. Leading the list of those foods which will likely be higher are crop foods in the first quarter and red meats and poultry in the second quarter. Larger beef supplies may prevent major increases in beef prices. The volume of food consumed per capita may be slightly less than last year, with increases in crop foods partially offsetting some decline in livestock and livestock products. Consumers will spend a somewhat higher proportion of their incomes on food.

Livestock farmers should experience a somewhat improved profit picture this year. Livestock prices are expected to increase as smaller quantities of most livestock products are marketed. Crop prices are believed to be sufficiently high to provide incentive for major increases in production, given a normal growing season. Feed prices may thus decline further in the second half of the year. With somewhat lower feed prices, feeding margins should increase, leading to higher profits and providing incentive for livestock expansion in late 1975 and early 1976.

While the production and price outlook for both livestock and crops this year is subject to much uncertainty, both gross farm income and farm production expenses are expected to rise. Expenses, however, may rise at a somewhat higher rate than income, and net farm incomes are likely to be below the 1974 level.

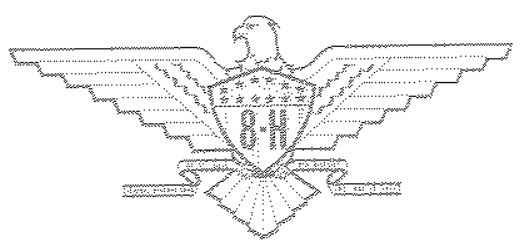

